\title{
Anabases
}

ANABASES Traditions et réceptions de l'Antiquité

22 | 2015

Varia

\section{Tragedy and History. About a Recent Book on Arnold Toynbee}

Vito Limone

\section{(2) OpenEdition \\ 12 Journals}

Electronic version

URL: http://journals.openedition.org/anabases/5511

DOI: 10.4000/anabases.5511

ISSN: 2256-9421

Publisher

E.R.A.S.M.E.

\section{Printed version}

Date of publication: 20 October 2015

Number of pages: 264-267

ISSN: $1774-4296$

\section{Electronic reference}

Vito Limone, «Tragedy and History. About a Recent Book on Arnold Toynbee », Anabases [Online], 22 |

2015, Online since 20 October 2018, connection on 20 October 2019. URL : http://

journals.openedition.org/anabases/5511 ; DOI : 10.4000/anabases.5511

(C) Anabases 
insulaire d'Ibiza ${ }^{107}$, afin de dépasser l'image d'un paysage phénicien urbain et maritime au profit d'une étude approfondie des occupations dans leur environnement.

Élodie Guillon

Université Toulouse-Jean Jaurès (UT2J) PLH-ERASMe - Maison de la Recherche

5, allées Antonio Machado

3ı 58 Toulouse Cedex 9

eguillon3ı@gmail.com

\section{Tradition de la pensée politique}

\section{Tragedy and History. About a Recent Book on Arnold Toynbee ${ }^{108}$ \\ Vito Limone}

The main aim of this book by Federico Leonardi is to propose a new view of Arnold Toynbee's philosophy of history, tracing its roots back to a little known lecture the British historian delivered in Oxford on May I920, The Tragedyof Greece. In fact, the book's appendix contains the first Italian translation of the lecture (The Tragedy of Greece. A Lecture Delivered for the Professor of Greek to Candidates for Honours in Literae Humaniores at Oxford in May I920, Clarendon Press, Oxford I92I). In this conference Toynbee sketched his view of the civilization, that later he applied in his masterpiece, A Study of History, whose twelve volumes were composed and immediately edited by Oxford University Press between I934 and ig6r. Critics always agreed that Toynbee was irenistic and they dismissed his mix of history and theology, whereas Leonardi puts forward that Toynbee was tragic and consequently to understand history is to recognise its tragedy and to seek an alternative, a reconcilation.

107 C'est l'objet d'un programme de recherche de deux ans financé par l'idex ATs Patrimoine de Toulouse: “Phéniciens et Puniques à Ibiza. VII ${ }^{\mathrm{e}}-\mathrm{III}^{\mathrm{e}}$ siècles av. J.-C. Patrimoine archéologique et modélisation spatiale».

108 Federico LeOnardi, Tragedia e storia. Arnold Toynbee: la storia universale nella maschera della classicità, Aracne, Atene e Gerusalemme 9, Roma 2014, I6o p. 
The book is divided into three parts: firstly, an introductory essay reconstructs the most important topics of Toynbee's lecture on the basis of his cultural and philosophical personality; secondly, Leonardi reports a detailed, although selected bibliography of Toynbee's works in which he lists not only the most remarkable books, articles and essays about different questions, from ancient civilization in general to Greek-Roman civilization, but he also suggests to the reader the corresponding Italian translations and the most useful critical literature; finally, the last and and very interesting part consists in the first translation into Italian of the above mentioned lecture, The Tragedy of Greece, and of another lecture which he gave in Madrid on October ig5i (Cómo la historia greco-romana ilumina la historia general, Rústica, Madrid I952), while he was accomplishing his A Study of History. Leonardi's choice of editing these two lectures, the first dated I920, the second I95I, is not accidental: in fact this allows the reader not only to compare Toynbee's ideas before the redaction of his masterpiece with his ideas at the end of his project, but also to recognize that his philosophy of history and his image of the civilization are almost the same from I920 to I951. And Leonardi's essay, which is a convincing critical presentation of this philosophy of history and this image of civilization, helps to acknowledge this conceptual continuity.

As Leonardi clearly shows in the first part of the book, Toynbee's philosophical position, especially his interpretation of the historical process, must be comprehended considering the cultural context, e.g. French, German, British historiography among $18^{\text {th }}$ and $19^{\text {th }}$ century. One of the first and most significant works about this topic was F.R. Chateaubriand's Essai historique sur les révolutions, published in I797 (whose following English translation, Historical, political and moral essay on revolutions, was published in London in I8I5, immediately after Napoleon's fall): in this book Chateaubriand insisted on the identity between revolutionary Athens, on the one hand, and revolutionary Paris, on the other hand. Neverthless, B. Constant in his De la liberté des Anciens comparée à celle des Modernes, an address delivered at the Athénée Royal de Paris in i8ıg, and F.De Coulanges' La Cité antique, published in i864, stated that one of the most evident mistakes of $18^{\text {th }}$ century historiography was the wrong stance about the political and cultural identity between ancient and modern societies. However, although $\mathrm{I}^{8^{\text {th }}}$ century historians thought that there was no difference between ancient and modern political systems, they introduced an important principle of historiography, i.e. the analogy. In fact they argued that ancient people, particularly Greeks, had a political system similar to modern politics, particularly French politics, because of an analogical comparison. The analogy became an important background through which to analyze historical events.

While in France the historiography alternated a successful judge about the analogical continuity among Ancients and Moderns and an austere criticism regarding this continuity, in England the publication of E. Gibbon's The history of the decline and fall on the Roman Empire, between 1776 and 1788 , imprinted a confirmation to the application of analogical method to historiography: the idea of the Commonwealth, for instance, seemed to have been preceded and anticipated by the Dealian League, built by Athens in $5^{\text {th }}$ century b.C.Moreover, in Germany, some years later, the historiography became a proper Altertumswissenschaft, particularly according to E. Meyer's Geschichte der Altertums, published between I884 and I902, in which he extended the historiographical observation not only to Europe, but also to eastern people, and he strictly associated the historiographical research with the sciences of antiquity. These were the premises on the basis 
of which Toynbee formulated his idea of history, in particular ancient history: a) there is no identity between ancient and modern civilizations, but analogy, and an analogical relationship implies that, although there must be lots of similar topics in common between the civilizations which are compared, there must be also some differences; b) the research in antiquity and in ancient history is proper a science and it interacts with other sciences of antiquity, e.g. the philology, although its method is analogical. This entire cultural context is well expressed by Leonardi in his introductory essay, and it suggests to the reader a clear image of the ideological and literary environment which influenced his works, included the lecture The Tragedy of Greece.

Toynbee's view of history, as Leonardi states, is based on two main ideas. Firstly, he believes that Greek-Roman history is the model according to which the entire history of Europe can be interpreted. Leonardi explains that this concept is expressed by O.Spengler in his masterpiece, Der Untergang des Abendlandes. Umrisse einer Morphologie der Weltgeschichte, published in two volumes in I9I8 and I922, where he focuses on the so called "Faustian Civilization". According to Leonardi's hypothesis, Toynbee's idea that the GreekRoman history is the model of the entire history and that it is possible to build a universal history on this basis depends on Spengler's image of the "Faustian Civilization". The other main idea of Toynbee's philosophy of history is the "tragicity" of Europe, which, on the one hand, tries to create a universal and total image of history, also on Greek-Roman model and, on the other hand, can not enclose the events into an inclusive and conceptual model. This contradiction, which is analyzed by Toynbee, is well expressed by F. Nietzsche, particularly in his Die Geburt der Tragödie, published in I872, and Unzeitgemässe Betrachtungen, composed between I873 and I876. Spengler and Nietzsche, as Leonardi clearly argues, are the two main sources of Toynbee's conception of World History and of Ancient History. Moreover, according to these two premises - the world history's claim to totality and the "tragicity" of this cultural project - Toynbee defines his image of Greek-Roman history. In particular, since the lecture that he delivered in 1920 he declares that the entire GreekRoman history can be divided into three acts: I) the first act corresponds to the period between $9^{\text {th }}$ century b.C. and 43I b.C., during which there were the birth and the evolution of Greek civilization, the increase of the póleis, the Greco-Persian Wars, the foundation of the Delian League as defense against external enemies;2) the second act corresponds to the period between 43I b.C. and 3i b.C. and consists in the succession of different sovereignties, i.e. the Athenians, the Spartans, the Thebans, finally the Macedonians and the Romans; 3) the third act corresponds to the period between 3I b.C. and $7^{\text {th }}$ century a.D., which is entirely characterized by the supremacy of Roman Empire and its final, necessary decline.

Leonardi suggests that, according to Toynbee's interpretation of history, the civilization is always at a crossroad and is constantly bound to make choices : on the one hand, the civilization has the opportunity to go beyond its boundaries, extend its power and be always involved into war; on the other hand, each civilization has the opportunity to mediate with other civilizations and so benefit from the results of this mediation. History, as Leonardi clearly explains, is always a history of civilizations, and each civilization is always at a crossroad and can either choose its own destruction, which results from its extension and the growth of its power, or its salvation, which comes from its mediation with other civiliza- 
tions and, in other terms, a limitation of her its power. The history of civilizations is essentially tragic, i.e. is always called to opt her ruin or its salvation.

Leonardi gave us a new image of Toynbee's philosophy, without sparing some hard critics to the British historian. Nevertheless, highlighting Toynbee's virtues and flaws, Leonardi dares to hint at a new philosophy of history, balancing the relation between classical antiquity and the future of the West.

Vito Limone Università Vita e Salute San Raffaele Via Olgettina 58 20132 - Milano (Italia) vitolimone@alice.it 